Transactions of the VŠB - Technical University of Ostrava, Mechanical Series

No. 2, 2013, vol. LIX

article No. 1953

\title{
Sándor BODZÁS*, Illés DUDÁS*** \\ COMPARATIVE FINITE ELEMENT METHOD ANALYSIS OF SPIROID WORM GEAR DRIVES HAVING ARCHED PROFILE AND HAVING LINEAR PROFILE IN AXIAL SECTION
}

\author{
ANALÝZA SROVNÁVACÍ METODY KONEČNÝCH PRVKU゚ ŠROUBOVITÉHO \\ OZUBENÉHO ŠNEKOVÉHO PŘEVODU S KLENUTÝM PROFILEM A LINEÁRNÍM \\ PROFILEM V AXIÁLNÍM ŘEZU
}

\begin{abstract}
With the knowledge of the advantageous characteristics of the cylindrical worm gear drives having arched profile in axial section and the conical worm gear drives having linear profile in axial section, a new geometric type conical worm gear drive has been designed and then manufactured, that is the conical worm gear drive having arched profile in axial section. Beside similar charging and marginal conditions in case of the same geometric spiroid worm gear drives having arched profile and having linear profile in axial section we have done comparative finite element method analysis for awarding of the strains, deformations and stresses of this gear drives.

\section{Abstrakt}

Byl navržen a vyroben nový geometrický typ kuželového šnekového převodu s klenutým profilem v axiálním řezu na základě znalostí výhodných charakteristik válcového šnekového převodu $\mathrm{s}$ klenutým profilem $\mathrm{v}$ axiálním řezu a kuželového šnekového převodu $\mathrm{s}$ lineárním profilem v axiálním řezu. Kromě podobných napájecích a dalších okrajových podmínek v př́ípadě stejných geometrických profilů ozubení se šnekovým převodem s klenutým a lineárním profilem v axiálním řezu jsme provedli analýzu srovnávací metody konečných prvků pro ohodnocení tlaků, deformací a napětí těchto ozubených převodů.
\end{abstract}

\section{Keywords}

spiroid, stress, strain, deformation

\section{INTRODUCTION}

With the knowledge of the advantageous characteristics of the cylindrical worm gear drives having arched profile in axial section and the conical worm gear drives having linear profile in axial section, a new geometric type conical worm gear drive has been designed and then manufactured, that is the conical worm gear drive having arched profile in axial section [2] (Figure 2.a).

The conical worm and face gear paired spiroid drives can be used for example as jointless drives of robots and tool machines.

* Department of Technical Preparatory and Production Engineering, College of Nyíregyháza, H-4400 Nyíregyháza, Sóstói u. 31/B., Hungary

*** Department of Production Engineering, University of Miskolc, H-3515 Miskolc, Egyetemváros, Hungary 
Power dissipation in the gear can be reduced significantly with these modern drive pairs which are characterized by favourable hydrodynamic conditions, great strength and high efficiency $[1,4]$.

\section{CAD MODELS PREPARATION}

The two parameric equations of the left helicoidal surface of the worm in rotating coordinate system can be produced (Figure 1):

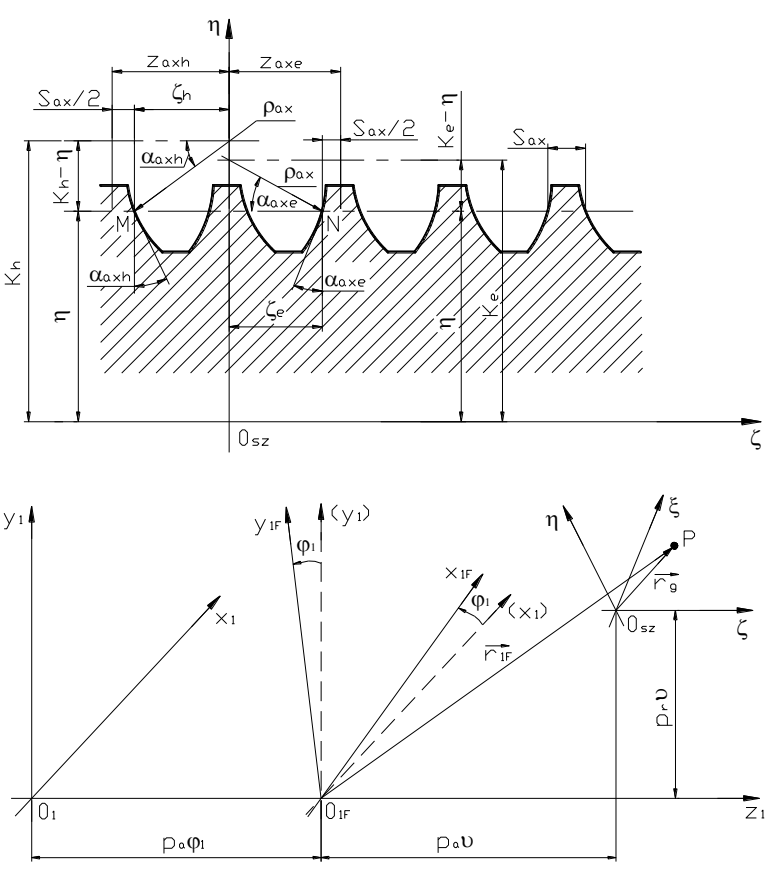

Fig. 1 Determination of the generator in the main section, in the axial section plane

$$
\left.\begin{array}{l}
x_{1 F}=-\eta \cdot \sin \vartheta \\
y_{1 F}=\eta \cdot \cos \vartheta+p_{r} \cdot \vartheta \\
z_{1 F}=p_{a} \cdot \vartheta+\sqrt{\rho_{a x}^{2}-\left(K_{e}-\eta\right)^{2}}
\end{array}\right\}
$$

The connection lines as wrapping surface generating tooth surface of element 2 , that is the equations of face gear tooth surface $[1,3,5]$ :

$$
\left.\begin{array}{l}
\vec{n}_{1 F} \cdot \vec{v}_{1 F}^{(12)}=0 \\
\vec{r}_{1 F}=\vec{r}_{1 F}(\eta, \vartheta) \\
\vec{r}_{2 F}=M_{2 F, 1 F} \cdot \vec{r}_{1 F}
\end{array}\right\}
$$

Knowing of the two parametric equations of spiroid worm having arched profile in axial section /1/ the CAD models of this gear drive has been carried out based on the double wrapping method (Figure 2.a). 

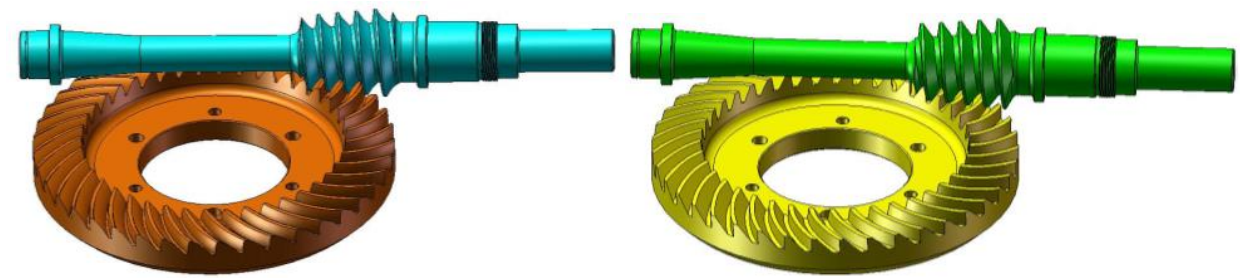

Fig. 2 CAD modelling a) spiroid worm gear drive having arched profile in axial section, b) spiroid worm gear drive having linear profile in axial section

The CAD models of the spiroid worm gear drives having linear profile in axial section has been carried out with similar double wrapping method (Figure 2.b).

Tab. 1 The geometric data of the examined spiroid gear drives

\begin{tabular}{|c|c|c|}
\hline Geometric parameters & $\begin{array}{c}\text { Spiroid worm gear drive having } \\
\text { linear profile in axial section }\end{array}$ & $\begin{array}{c}\text { Spiroid worm gear drive having } \\
\text { arched profile in axial section }\end{array}$ \\
\hline Worm number of threads & 1 & 1 \\
\hline Face gear tooth number & 41 & 41 \\
\hline Module & $5 \mathrm{~mm}$ & $5 \mathrm{~mm}$ \\
\hline Centre distance & $100 \mathrm{~mm}$ & $100 \mathrm{~mm}$ \\
\hline Low side profile angle & $10^{\circ}$ & $16^{\circ}$ \\
\hline High side profile angle & $30^{\circ}$ & $37^{\circ}$ \\
\hline Worm half cone angle & $5^{\circ}$ & $5^{\circ}$ \\
\hline Worm material & \multicolumn{2}{|c|}{ Bzö 12 } \\
\hline Face gear material & \multicolumn{2}{|c}{} \\
\hline
\end{tabular}

\section{THE ADOPTION OF THE FINITE ELEMENT MESH}

In both cases triangle mesh generation has been used in case of the adoption of finite element mesh (Figure 3). The connection zone has been occurred with denser 0,5 mm mesh adoption (Figure 3).

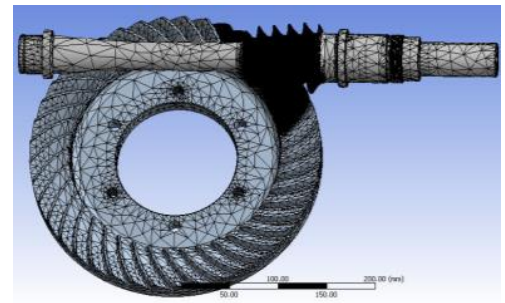

Fig.3 The adoption of the finite element mesh (the number of nodes: 1506197, the number of elements: 1009989)

\section{SETTING OF CHARGING AND MARGINAL CONDITIONS}

In both cases for setting of charging and marginal conditions fixed support has been used on the right side worm shaft bearing place, the face gear holes and the face gear deposition $[3,5]$. On the left side worm shaft bearing place the directional displacement $\mathrm{x}$ is permited, but the directional displacement $\mathrm{y}$ and $\mathrm{z}$ are held (Figure 4). The worm shaft has been charged by loading moment $760 \mathrm{Nm}$ [4]. 


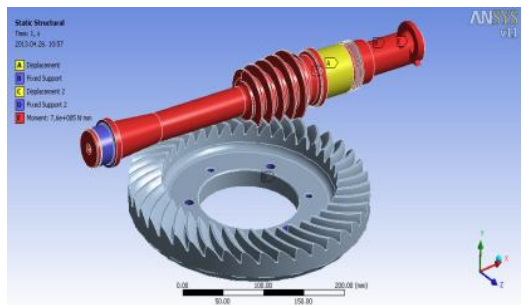

Fig. 4 Setting of charging and marginal conditions

\section{STRESS DISTRIBUTION ANALYSIS}

The position coordination of a random point of the space is [6]:

$$
\vec{r}_{P}=x \cdot \vec{e}_{x}+y \cdot \vec{e}_{y}+z \cdot \vec{e}_{z}
$$

A stress tensor is in general case [6]:

$$
\underline{\underline{T_{P}}}\left(\vec{r}_{P}\right)=\left[\begin{array}{lll}
\sigma_{x} & \tau_{x y} & \tau_{x z} \\
\tau_{y x} & \sigma_{y} & \tau_{y z} \\
\tau_{z x} & \tau_{z y} & \sigma_{z}
\end{array}\right]
$$
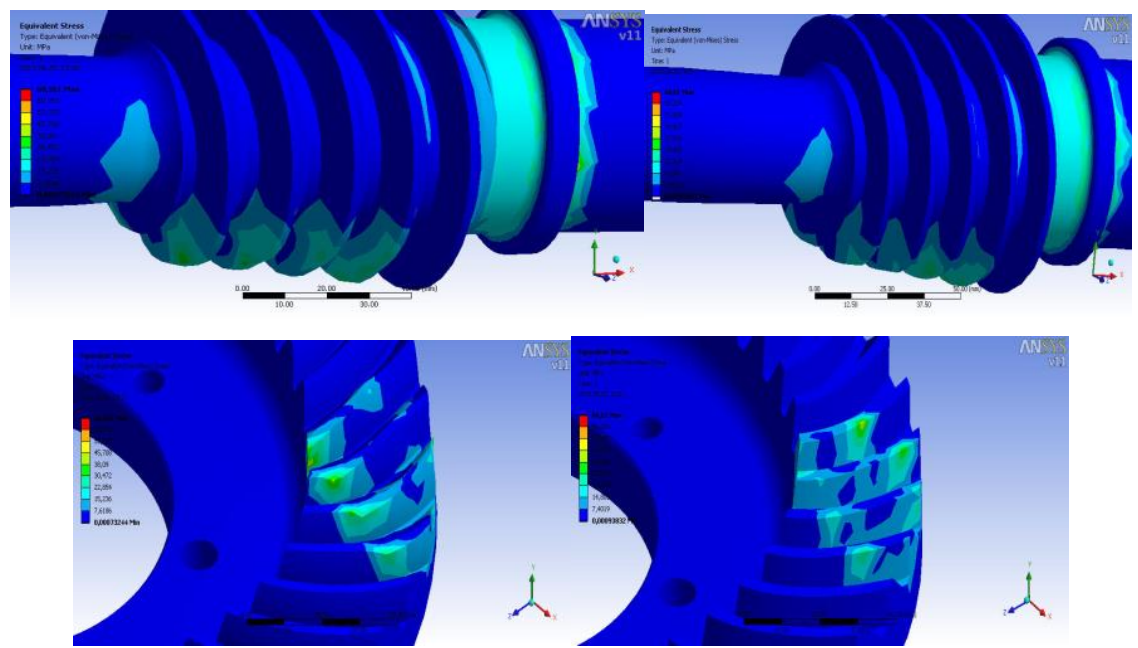

Fig. 5 Equivalent stress distribution a) spiroid worm having arched profile in axial section, b) spiroid worm having linear profile in axial section, c) face gear having curved profile, d) face gear having linear profile

The equivalent stress is characterized the pointed stress condition in terms of bankruptcy [6].

Inscribing the equivalent stress the general spatial stress condition could be attributed for special simple case. The equivalent stress has been defined by the Huber - Mises - Hencky theory [6]:

$$
\sigma_{\text {red (HMH) }}=\sqrt{\frac{1}{2} \cdot\left[\left(\sigma_{x}-\sigma_{y}\right)^{2}+\left(\sigma_{y}-\sigma_{z}\right)^{2}+\left(\sigma_{y}-\sigma_{z}\right)^{2}+6 \cdot\left(\tau_{x y}^{2}+\tau_{y z}^{2}+\tau_{x z}^{2}\right)\right]}
$$

On Figure 5 it could be seen the highest equivalent stress values are developed on the connection zone of cogs connections between conical worm and face gear. During gear drive working four face gear cogs are connected simultaneously with the worm. When one $\operatorname{cog}$ is 
entered to the connection firstly it is connected with worm on the right side of face gear surface after the connection zone is slided continously to the left side depending on turning to the face gear axis direction. Reaching the exit form the connection the connection zone will be the left side of the face gear surface (Figure 5.b, d).

On Figures 5.b and 5.d it could be seen in case of spiroid worm gear drive having arched profile in axial section the equivalent stress values are higher with $2 \mathrm{MPa}$ but the stress distribution on the face gear surface are more equable than using linear profile.

Knowing of the stress tensor the normal stress to the normal vector $\vec{n}$ direction is [6]:

$$
\sigma_{n}=\vec{n} \cdot \underline{\underline{T_{P}}} \cdot \vec{n}
$$
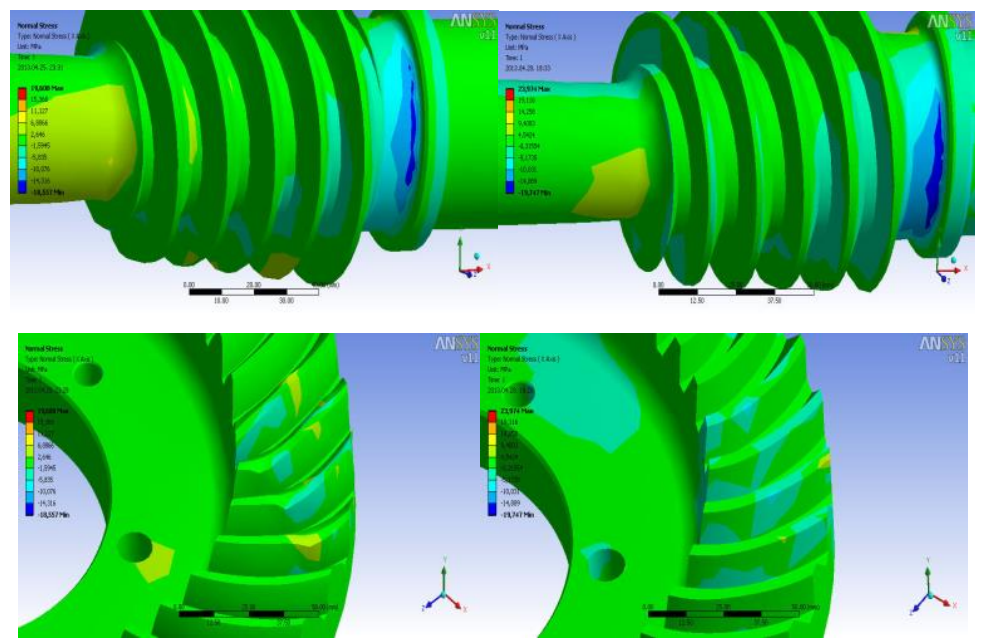

Fig. 6 Normal stress distribution a) spiroid worm having arched profile in axial section, b) spiroid worm having linear profile in axial section, c) face gear having curved profile, d) face gear having linear profile

On Figure 6 it could be seen in case of conical worm gear drive having arched profile in axial section the connection acting normal stress values are smaller with $4 \mathrm{MPa}$ than using linear profile.

\section{EQUIVALENT ELASTIC STRAIN DISTRIBUTION ANALYSIS}

The deformation tensor and its scalar coordinates are defined [6]:

$$
\begin{gathered}
A_{P}\left(\vec{r}_{P}\right)=\left[\begin{array}{ccc}
\varepsilon_{x} & \frac{1}{2} \gamma_{x y} & \frac{1}{2} \gamma_{x z} \\
\frac{1}{2} \gamma_{y x} & \varepsilon_{y} & \frac{1}{2} \gamma_{y z} \\
\frac{1}{2} \gamma_{z x} & \frac{1}{2} \gamma_{z y} & \varepsilon_{z}
\end{array}\right] \\
\varepsilon_{x}=\frac{\partial u}{\partial x}, \ldots, \gamma_{x y}=\frac{\partial u}{\partial y}+\frac{\partial v}{\partial x}, \ldots
\end{gathered}
$$

The equivalent elastic strain is [6]:

$$
\varepsilon_{e}=\sqrt{\varepsilon_{x}^{2}+\varepsilon_{y}^{2}+\varepsilon_{z}^{2}}
$$



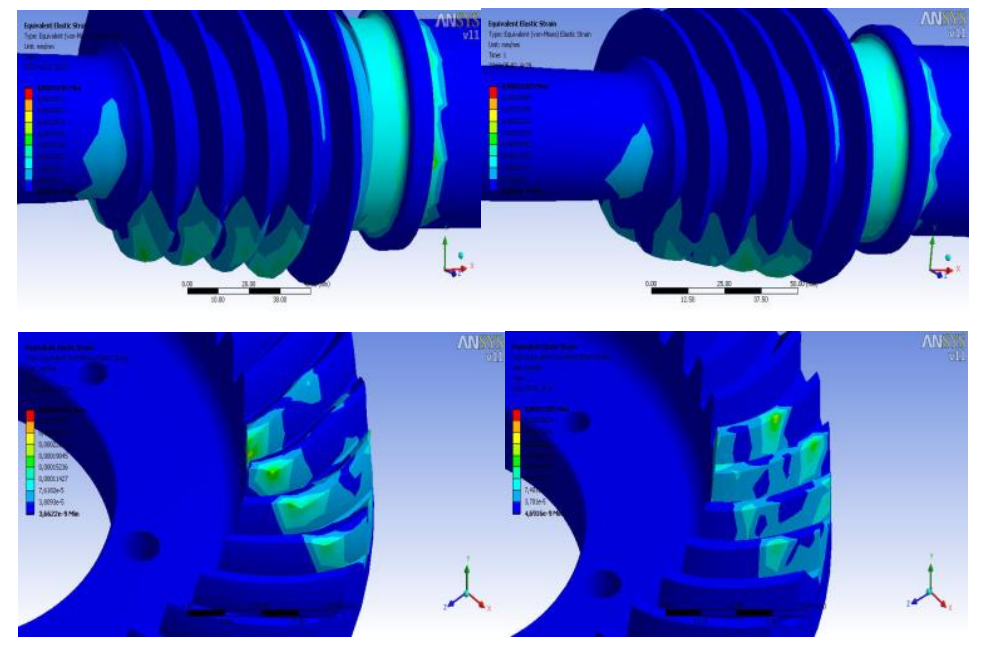

Fig. 7 Equivalent elastic strain distribution a) spiroid worm having arched profile in axial section, b) spiroid worm having linear profile in axial section, c) face gear having curved profile, d) face gear having linear profile

On Figure 7 it could be seen the equivalent elastic strain values are equal practically at the same time the strain values distributions are more equable than using linear profile.

\section{DEFORMATION DISTRIBUTION ANALYSIS}

A finite element node has three freedom degrees so during deformation one node could have $\mathrm{u}, \mathrm{v}, \mathrm{w}$ directional deformation (displacement) to the three freedom degrees [7]. So the displacement field is [6]:

$$
\vec{u}=\vec{u}\left(\vec{r}_{P}\right)=u \cdot \vec{e}_{x}+v \cdot \vec{e}_{y}+w \cdot \vec{e}_{z}
$$

Where the length of displacement vector which is the values of total deformation is [6]:

$$
\|\vec{u}\|=\sqrt{u^{2}+v^{2}+w^{2}}
$$

During our examinations the total deformation and the axis $\mathrm{x}$, that is the worm shaft direction, deformation are analysed, since during the gear drive working the axial direction is determining.
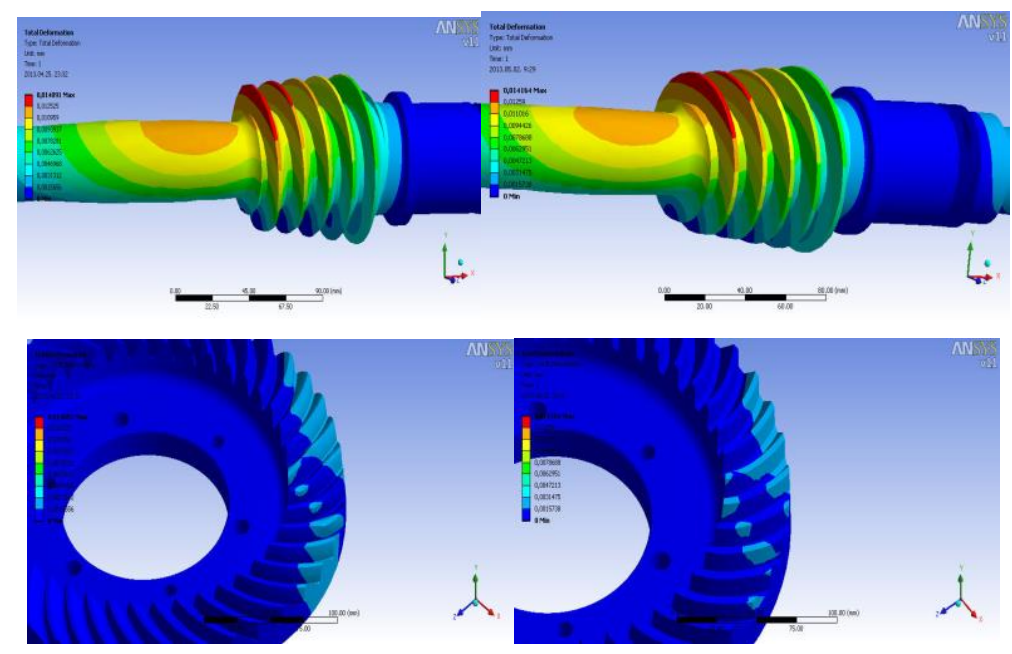


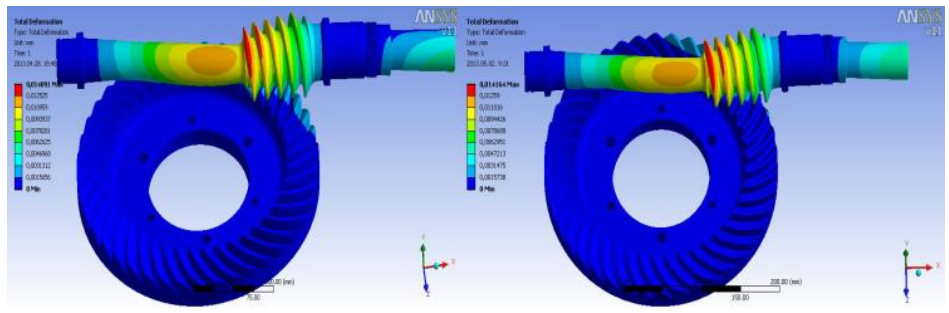

Fig. 8 Total deformation distribution a) spiroid worm having arched profile in axial section, b) spiroid worm having linear profile in axial section, c) face gear having curved profile, d) face gear having linear profile, e) spiroid worm gear drive having arched profile in axial section, $f$ ) spiroid worm gear drive having arched profile in axial section

On Figures 8 and 9 it could be seen during the worm tooth surface the deformation values are reduced to the smallest diameters since the moment transmitting is occurred on the left shaft end on the key. That is why the charging of the connection face gear cogs is not equable. On connection, face gear cogs nearer to the worm key are charged better than face gear cogs farther to the key joint.

On Figure 8 it could be seen the total deformation values are concurrent practically in case of both gear drives.

On Figure 9 it could be seen the direction deformation $x$ values are equal in case of both gear drives. Comparing Figure 9.a and 9.b it could be seen in case of gear drive having linear profile in axial section (Figure 9.b) the maximum deformation value is higher and expanded to much tooth surface then using arched profile.
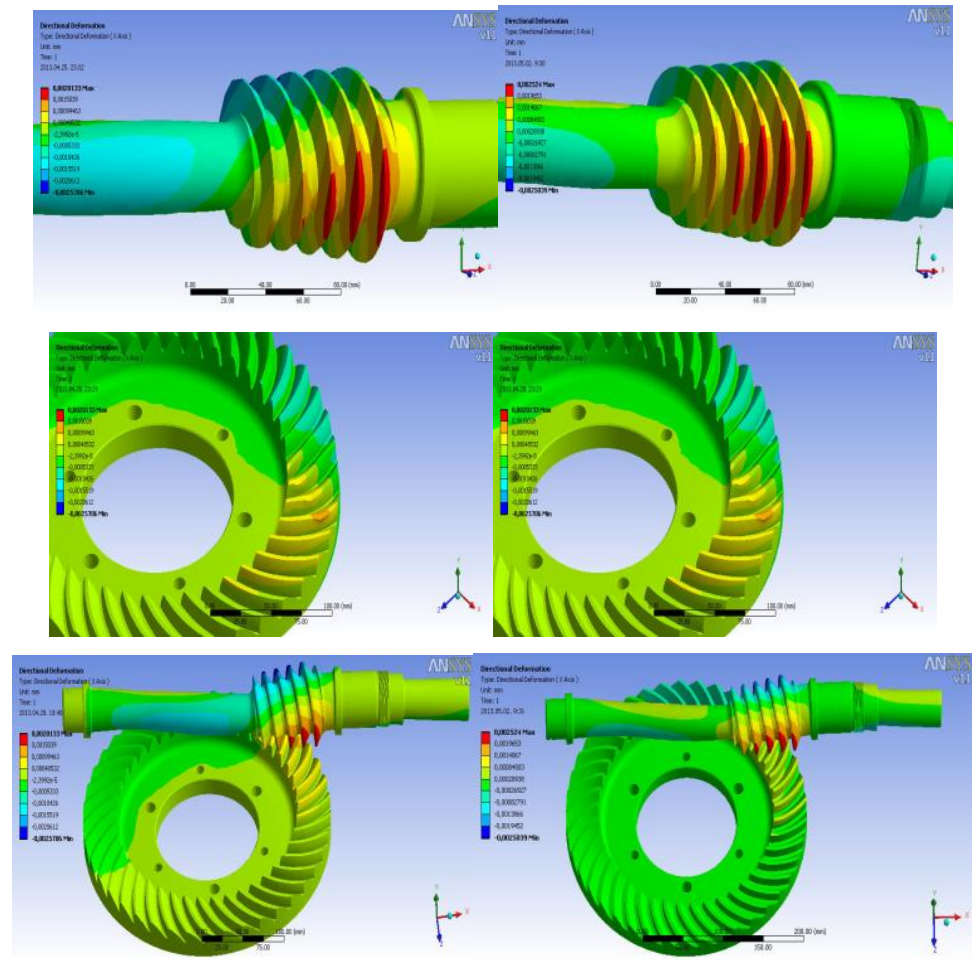

Fig. 9 Direction deformation $x$ distribution a) spiroid worm having arched profile in axial section, b) spiroid worm having linear profile in axial section, c) face gear having curved profile, d) face gear having linear profile, e) spiroid worm gear drive having arched profile in axial section, f) spiroid worm gear drive having arched profile in axial section 


\section{CONCLUSIONS}

With the knowledge of the advantageous characteristics of the cylindrical worm gear drives having arched profile in axial section and the spiroid worm gear drives having linear profile in axial section, a new geometric type conical worm gear drive, the spiroid worm gear drive having arched profile in axial section has been designed [2].

Beside similar charging and marginal conditions we have done comparative finite element method analysis for awarding of the mechanical characteristics of spiroid worm gear drive having arched profile and linear profile.

It could be determinable the our designed spiroid worm gear drive having arched profile in axial section has advantageous stress, strain and deformation values than the same geometric spiroid worm gear drive having linear profile in axial section.

\section{ACKNOWLEDGEMENTS}

The actual production of the conical worm gear drive pair having arched profile in axial section has taken place in Miskolc, by DifiCAD Engineering Office Ltd. (5-7. Szentpéteri Gate, Miskolc). CEO: Dr. Illés Dudás

\section{REFERENCES}

[1] DUDÁS, I.: The Theory and Practice of Worm Gear Drives. Penton Press, London, 2000. (ISBN 185718027 5)

[2] DUDÁS I., BODZÁS S., DUDÁS I. SZ., MÁNDY Z.: Konkáv menetprofilú spiroid csigahajtópár és eljárás annak köszörüléssel történő elöállitására, Szabadalmi iktatószám: P1200405, Szabadalmi bejelentés napja: 2012.07.04.

[3] FUENTES, A. A., GONZÁlEZ, P. I.: Análisis Tensional por Elementos Finitos de Engranajes Rectos con Geometría Modificada, Revista Iberoamericana de Ingeniería Macánica, vol. 8, No 1, pp. 15-30, 2004.

[4] HEGYHÁTI, J.: Untersuchungen zur Anwendung von Spiroidgetrieben. Diss. A. TU. Dresden, 1988. p. 121.

[5] LiTVIN, F. L., GONZÁlEZ, P. I., YUKISHIMA, K., FUENTES, A. A., HAYASAKA, K.: Design, Simulation of Meshing and Contact Stresses for an Improved Worm Gear Drive, Mechanism and Machine Theory, Elsevier, pp. 940-959, 2006.

[6] PÁCZELT, I., SZABÓ, T., BAKSA, A.: A végeselem módszer alapjai, Értékünk az ember, Humánerőforrás fejlesztési Operatív Program, Miskolci Egyetemi Elektronikus jegyzet

[7] SZABÓ, F., BIHARI, Z., SARKA, F.: Termékek, szerkezetek, gépelemek végeselemes modellezés és optimálása, Szakmérnöki jegyzet, Miskolc, 2006.

[8] ZWIERCZYK, P., VÁRADI, K.: Vasúti sín-kerékabroncs kapcsolat súrlódási állapotának végeselemes vizsgálata. GÉP LXIII (12), pp. 159-162. 2012 